\title{
Four Phragmalin Orthoesters from the Chinese Mangrove Xylocarpus granatum
}

Authors

Affiliations
Zhen-Fang Zhou ${ }^{1 *}$, Ling-Yi Kong ${ }^{2 *}$, Tibor Kurtán ${ }^{3}$, Hai-Li Liu ${ }^{1}$, Attila Mándi ${ }^{3}$, jia Li ${ }^{1}$, Yu-Cheng Gu ${ }^{4}$, Yue-Wei Guo ${ }^{1}$

1 Shanghai Institute of Materia Medica, Chinese Academy of Sciences, Shanghai, China

2 State Key Laboratory of Natural Medicines, Department of Natural Medicinal Chemistry, China Pharmaceutical University,

Nanjing, China

${ }^{3}$ Department of Organic Chemistry, University of Debrecen, Debrecen, Hungary

${ }^{4}$ Syngenta Jealott's Hill International Research Centre, Berkshire, United Kingdom
Key words

- Meliaceae

- Xylocarpus granatum

- phragmalin orthoesters

- configuration determination

- biological activity received Sept. 26, 2013

revised June 6, 2014

accepted June 12, 2014

\section{Bibliography}

DOI http://dx.doi.org/

10.1055/s-0034-1382840

Published online July 16, 2014

Planta Med 2014; 80: 949-954

(c) Georg Thieme Verlag KG

Stuttgart - New York .

ISSN 0032-0943

\section{Correspondence}

Prof. Dr. Yue-Wei Guo

State Key Laboratory of Drug

Research

Shanghai Institute of Materia Medica

Chinese Academy of Sciences

Zu Chong Zhi Rd. 555,

Zhangjiang Hi-Tech Park

Shanghai 201203

People's Republic of China

Phone: + 862150805813

Fax: + 862150805813

ywguo@mail.shcnc.ac.cn

\section{Abstract \\ $\nabla$}

Four new 8,9,30-phragmalin orthoesters (1-4), along with six related known compounds, namely xyloccensins $\mathrm{O}-\mathrm{S}(\mathbf{5 - 9})$ and $\mathrm{V}(\mathbf{1 0})$, were isolated and characterized from the twigs and leaves of the Chinese mangrove Xylocarpus granatum. The structures of the new compounds were determined on the basis of extensive spectroscopic analysis and by comparison with those of related known compounds in the literature. The absolute configuration of xyloccensin $Q(7)$ was revised as its enantiomer by X-ray diffraction analysis employing graphite monochromated $\mathrm{Cu} \mathrm{K} \alpha$ radiation

\section{Introduction}

\section{$\nabla$}

The orthoester, a functional group that features three alkoxy groups attached to a single carbon atom, has been widely discovered as a structural subunit in natural products of plant origin [1]. The orthoester-containing compounds usually show prominent pharmacological activities such as cytotoxic, antifeedant, insecticidal properties, etc. [1]. Limonoid orthoesters are characterized by the presence of a highly oxygenated limonoid skeleton containing an orthoester functionality, which exists exclusively as phragmalin orthoesters and can be classified into 1,8,9-, 8,9,11-, $8,9,12-, 8,9,14-$, and 8,9,30-types according to the position of the orthoester group in the phragmalin limonoid skeleton [1]. Due to the structural complexity of phragmalin orthoesters, the structural characterization, in particular, of the absolute configuration has been a challenging task. Although, until now, about 90 phragmalin orthoesters have been reported from the plant belonging to two tribes (Swietenieae and Xylocar-

\footnotetext{
${ }^{*}$ These two authors contributed equally to this work.
}

$(\lambda=1.54178 \AA$ ) with a Flack parameter of -0.04 and was further secured by a time-dependent density functional theory electronic circular dichroism (TDDFT ECD) calculation. Consequently, the absolute configurations of xyloccensins $\mathrm{O}(5)$, $\mathrm{P}(\mathbf{6}), \mathrm{R}(\mathbf{8}), \mathrm{S}(\mathbf{9})$, and V (10) were all corrected as their corresponding enantiomers, respectively. Xyloccensin S (9) exhibited inhibitory activity against protein tyrosine phosphatase $1 \mathrm{~B}$, a potential drug target for the treatment of type II diabetes and obesity, with an $\mathrm{IC}_{50}$ value of $8.72 \mu \mathrm{g} / \mathrm{mL}$.

Supporting information available online at http://www.thieme-connect.de/products

peae) of the Meliaceae family [1]. To our knowledge, only ten phragmalin orthoesters belonging to two classes, 1,8,9- and 8,9,30-phragmalin orthoesters, were isolated from the Chinese mangrove Xylocarpus granatum Koenig [2-6].

Mangroves of the three species in the genus Xylocarpus (family Meliaceae) are widely distributed in the coastal areas of Southeast Asia, Australia, East Africa, and Indian Ocean. X. granatum has been used as folk medicine in Southeast Asia and India for the treatment of diarrhea, cholera, and fever diseases and is a rich source of limonoids [7]. Hitherto, more than 100 limonoids have been isolated from the fruits, seeds, seed kernels, and stem bark of $X$. granatum [6-21].

We now report the chemical investigation of the twigs and leaves of the title plant, since no other phytochemical study has been conducted on these parts before. Four new 8,9,30-phragmalin orthoesters (1-4) and six related known compounds (5-10) were found ( 0 Fig. 1 ). This paper includes revisions of the absolute configurations of xyloccensins O-S (5-9) and V (10), of which the absolute configurations were previously erroneously assigned [4]. 


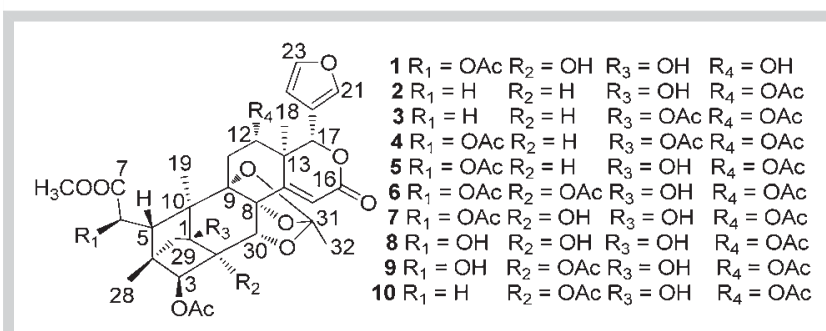

Fig. 1 Structures of compounds 1-10.

\section{Results and Discussion}

$\nabla$

The air-dried, powdered twigs and leaves $(2.0 \mathrm{~kg})$ of $X$. granatum were percolated exhaustively with $\mathrm{MeOH}$ at room temperature. The $\mathrm{MeOH}$ extract was partitioned between EtOAc and $\mathrm{H}_{2} \mathrm{O}$. The EtOAc-soluble portion was separated by Sephadex LH-20 and MCI gel column to obtain five fractions (1-5). Fraction 3 was repeatedly chromatographed over silica gel, Sephadex LH-20, and reverse-phase HPLC to afford ten phragmalin orthoesters (1-10), of which four are new compounds (1-4) and six are known ones previously isolated from the stem bark of the same plant $[2,4,5]$. The known phragmalins were identified by comparison of their spectroscopic data and $[\alpha]_{D}$ values with those reported in the literature as xyloccensins Q-S (7-9) and V (10), respectively. However, the measured optical rotation signs of both xyloccensins $\mathrm{O}$ (5) $\left\{[\alpha]_{\mathrm{D}}^{20}+62\right.$ (c 0.37, acetone) $\}$ and $\mathrm{P}(6)\left\{[\alpha]_{\mathrm{D}}^{20}+68\right.$ (c 0.13, acetone) $\}$ were the opposite from those reported by $\mathrm{Wu}$ et al. [2]. In order to clarify this confusion, the $[\alpha]_{D}$ values of xyloccensins 0 (5) and $\mathrm{P}(\mathbf{6})$ provided by Wu's group were remeasured, and the similar $[\alpha]_{D}$ values from Wu's samples $\left\{\right.$ xyloccensin $0:[\alpha]_{D}^{20}+56$ (c 0.4, acetone) $\}$; xyloccensin $\mathrm{P}\left\{[\alpha]_{\mathrm{D}}^{20}+49\right.$ (c 0.11 , acetone) $\}$ confirmed the correctness of our results.

Compound 1 had the molecular formula $\mathrm{C}_{33} \mathrm{H}_{38} \mathrm{O}_{15}$ as deduced from HRMS (ESI), 42 mass units less than the co-occurring compound xyloccensin Q (7). Its NMR data ( Table 1) showed great similarities with those of xyloccensin $Q(7)[4,5]$. In fact, the only difference between them was the absence of an acetyl moiety at $\mathrm{C}-12$ in 1 , which was evidenced by the lack of the characteristic ${ }^{13} \mathrm{C}$ NMR peaks in its ${ }^{13} \mathrm{C}$ NMR spectrum, and the significantly upfield-shifted proton signal of $\mathrm{H}-12$. Thus, the structure of 1 was determined as the 12-deacetyl derivative of xyloccensin $\mathrm{Q}(\mathbf{7})$.

Compound 2 had the molecular formula $\mathrm{C}_{33} \mathrm{H}_{38} \mathrm{O}_{13}$. Its ${ }^{1} \mathrm{H}$ and ${ }^{13} \mathrm{C}$ NMR spectroscopic data were reminiscent of those of xyloccensin $\mathrm{V}(\mathbf{1 0})[4,5]$. Comparison of the ${ }^{1} \mathrm{H}$ NMR spectroscopic data of $\mathbf{2}$ and xyloccensin $V(\mathbf{1 0})$ revealed that the main differences between them were the presence of a typical doublet of doublets and a pair of doublets, along with the lack of the acetoxyl group in the spectrum of $\mathbf{2}$, suggesting that $\mathbf{2}$ was a deacetoxyl derivative of xyloccensin V (10) at C-2, which was in good agreement with the 58 mass units difference. Thus, compound 2 was established as the 2-deacetoxyl derivative of xyloccensin $\mathrm{V}(\mathbf{1 0})$.

Compound 3 had the molecular formula $\mathrm{C}_{35} \mathrm{H}_{40} \mathrm{O}_{14}$. The NMR data of $\mathbf{3}$ were very similar to those of $\mathbf{2}$, except for the presence of an acetyl moiety in 3. Furthermore, the apparent downfieldshifted ${ }^{13} \mathrm{C}$ NMR resonance of $\mathrm{C}-1$ indicated that the 1-hydroxyl group was acetylated. Compound $\mathbf{3}$ was, therefore, determined as the 1-acetyl derivative of $\mathbf{2}$.

Compound 4 had the molecular formula $\mathrm{C}_{37} \mathrm{H}_{42} \mathrm{O}_{16}, 58$ mass units more than that of 3 . The ${ }^{1} \mathrm{H}$ and ${ }^{13} \mathrm{C}$ NMR spectroscopic data
( Table 2) of 4 were almost identical to those of the co-occurring compound 3; the only difference was the presence of an additional acetoxyl group in 4. This acetoxyl was located at C-6 based on the absence of a methylene in $\mathbf{3}$ accompanying the presence of a methine in $\mathbf{4}$. Thus, the structure of $\mathbf{4}$ was established. The singlet of H-6 required approximately $90^{\circ}$ of the dihedral angle between $\mathrm{H}-5 / \mathrm{H}-6$, indicating the stereochemistry of C-6 was the same as that of xyloccensin $\mathrm{R}(\mathbf{8})[4,5]$.

Because the main differences between the new compounds 1-4 and the co-occurring known phragmalin limonoids, xyloccensins O-S (5-9) and V (10), were the different positions of acetylation and deacetylation, the absolute configurations of these new compounds are likely to be the same. The absolute configurations of xyloccensins O-S (5-9) and V (10) have been determined by the modified Mosher's method in combination with ECD analysis [4]. Since xyloccensin Q (7) could be easily crystallized, to secure the correctness of the previously assigned absolute configuration mentioned above, the compound was submitted for X-ray diffraction analysis with a mirror $\mathrm{Cu} K \alpha$ radiation $(\lambda=1.54178 \AA$ ) (๑ Fig. 2). The absolute configuration of xyloccensin Q (7) was unambiguously assigned as $1 R, 2 R, 3 S, 4 R, 5 S, 6 R, 8 R, 9 S, 10 R, 12 S, 13 S$, $17 R, 30 R, 31 S$, opposite to that reported by Wu et al. [4].

To further support the configurational assignment of 7, we applied the solid-state TDDFT ECD method, which has been recently developed for the configurational assignment of natural products, since the conformational analysis step can be skipped [2225]. Both the solid-state and solution ECD spectra of 7 showed similar profiles with positive Cotton effects at 219 and $261 \mathrm{~nm}$, respectively. Four computed TDDFT ECD spectra, calculated for the DFT optimized X-ray geometry of $(1 R, 2 R, 3 S, 4 R, 5 S, 6 R, 8 R$, $9 S, 10 R, 12 S, 13 S, 17 R, 30 R, 31 S)-7$ with four different functions (B3LYP, BH\&HLYP, CAM- B3LYP, PBE0) and the TZVP basis set, reproduced the experimental solid-state ECD spectrum well (Supporting Information), confirming the absolute configuration of $\mathbf{7}$. In light of these observations, the absolute configuration of xyloccensin $Q$ (7) should be revised as its corresponding enantiomer. Accordingly, the absolute configurations of xyloccensins $\mathrm{O}$ (5), P (6), R (8), S (9), and V (10) should be corrected as their corresponding enantiomers since their configurations were also determined by application of the same method used for xyloccensin $Q$ (7) [4]. Therefore, the ECD spectra of xyloccensins O (5), P (6), R (8), S (9), and V (10) were measured again. The similar ECD spectra of xyloccensins O-S (5-9) and V (10) (Supporting Information) clearly indicate that they are homochiral and, thus, their absolute configurations were revised as their corresponding enantiomers.

The absolute configurations of new compounds $\mathbf{2}$ and $\mathbf{3}$ were determined by comparing their ECD spectra with the related known compounds $\mathbf{5 - 1 0}$ since they bear the same chromophores, unsaturated $\delta$-lactone, and furan ring. Although the intensities and maxima were slightly different, the similar ECD pattern for compounds 2 and 3, which were governed by the C-13 and C-17 chirality centers, suggested an $R, R$ configuration for $\mathrm{C}-13$ and $\mathrm{C}-17$. The absolute configurations of compounds $\mathbf{1}$ and $\mathbf{4}$ were not determined directly because of the scarcity of material, but are assumed to be in the same series.

Although many phytochemical investigations have been reported on the fruits, seeds, seed kernels, and stem bark of $X$. granatum, this is the first report on the chemical constituents of the twigs and leaves of the Chinese mangrove $X$. granatum. It is interesting to note that the different parts of the plant can produce different metabolites. Specifically, the twigs and leaves of $X$. granatum 
Table 1 NMR data for compounds $\mathbf{1}$ and $\mathbf{2}$.

\begin{tabular}{|c|c|c|c|c|c|c|}
\hline \multirow[b]{2}{*}{ Position } & \multicolumn{3}{|l|}{1} & \multicolumn{3}{|l|}{2} \\
\hline & $\delta_{\mathrm{H}}(/ \mathrm{in} \mathrm{Hz})^{[\mathrm{a}]}$ & $\delta_{\mathrm{H}}(/ \text { in } \mathrm{Hz})^{[\mathrm{b}]}$ & $\delta_{C}^{[b]}$ & $\delta_{\mathrm{H}}(/ \text { in } \mathrm{Hz})^{[\mathrm{a}]}$ & $\delta_{\mathrm{H}}(J \text { in } \mathrm{Hz})^{[\mathrm{b}]}$ & $\delta_{C}^{[b]}$ \\
\hline 1 & & & $83.5, \mathrm{qC}$ & & & $81.7, \mathrm{qC}$ \\
\hline 2 & & & 76.7, qC & $3.09, \mathrm{dd}(12.0,4.0)$ & $3.15, \mathrm{dd}(12.0,3.7)$ & 44.6, $\mathrm{CH}$ \\
\hline 3 & $4.78, \mathrm{~s}$ & $4.52, \mathrm{~s}$ & $85.6, \mathrm{CH}$ & $5.36, d(12.0)$ & $5.29, d(12.0)$ & $77.7, \mathrm{CH}$ \\
\hline 4 & & & 44.9, qC & & & $46.1, \mathrm{qC}$ \\
\hline 5 & $2.53, \mathrm{~s}$ & $2.41, \mathrm{~s}$ & 44.9, qC & 2.33, d (12.0) & $2.30, d(12.3)$ & $40.8, \mathrm{CH}$ \\
\hline $6 a$ & $5.51, \mathrm{~s}$ & $5.42, \mathrm{~s}$ & $71.2, \mathrm{CH}$ & 3.17, d (17.0) & $2.23, d(17.5)$ & $32.4, \mathrm{CH}_{2}$ \\
\hline $6 b$ & & & & $2.48, \mathrm{dd}(17.0,12.0)$ & $1.99, \mathrm{~d}(17.5,12.3)$ & \\
\hline 7 & & & 171.3, qC & & & 174.5, qC \\
\hline 8 & & & $84.1, \mathrm{qC}$ & & & $82.0, \mathrm{qC}$ \\
\hline 9 & & & $87.4, \mathrm{qC}$ & & & $86.7, \mathrm{qC}$ \\
\hline 10 & & & $48.2, \mathrm{qC}$ & & & 47.7, qC \\
\hline $11 a$ & $2.29, \mathrm{dd}(13.7,4.0)$ & 2.29, dd $(12.3,3.6)$ & $34.2, \mathrm{CH}_{2}$ & $2.25, \mathrm{~m}$ & $2.25, \mathrm{dd}(15.0,3.8)$ & 33.0, $\mathrm{CH}_{2}$ \\
\hline $11 b$ & $2.06^{[c]}$ & $1.98, d(14.6)$ & & $2.04^{[c]}$ & $2.04^{[c]}$ & \\
\hline 12 & $4.04, \mathrm{dd}(13.7,4.0)$ & $3.98, d(12.3)$ & $66.5, \mathrm{CH}$ & $4.82, \mathrm{dd}(13.6,4.2)$ & $4.79, \mathrm{dd}(13.3,4.2)$ & $68.7, \mathrm{CH}$ \\
\hline 13 & & & $44.2, q C$ & & & $42.9, \mathrm{qC}$ \\
\hline 14 & & & 154.1, qC & & & 153.9, qC \\
\hline 15 & $6.82, \mathrm{~s}$ & $6.41, \mathrm{~s}$ & 123.4, $\mathrm{CH}$ & $6.71, \mathrm{~s}$ & $6.55, \mathrm{~s}$ & $123.0, \mathrm{CH}$ \\
\hline 16 & & & 163.4, qC & & & 163.6, qC \\
\hline 17 & $5.88, \mathrm{~s}$ & $5.90, \mathrm{~s}$ & 78.9, $\mathrm{CH}$ & $5.98, \mathrm{~s}$ & $5.98, \mathrm{~s}$ & $78.8, \mathrm{CH}$ \\
\hline 18 & $1.45, \mathrm{~s}$ & $1.48, \mathrm{~s}$ & $13.1, \mathrm{CH}_{3}$ & $1.52, \mathrm{~s}$ & $1.52, \mathrm{~s}$ & 14.4, $\mathrm{CH}_{3}$ \\
\hline 19 & $1.26, \mathrm{~s}$ & $1.30, \mathrm{~s}$ & $16.3, \mathrm{CH}_{3}$ & $1.24, \mathrm{~s}$ & $1.25, \mathrm{~s}$ & 14.6, $\mathrm{CH}_{3}$ \\
\hline 20 & & & 121.2, qC & & & $121.1, \mathrm{qC}$ \\
\hline 21 & $7.62, \mathrm{~s}$ & $7.65, \mathrm{~s}$ & $142.4, \mathrm{CH}$ & $7.48, \mathrm{~s}$ & $7.41, \mathrm{~s}$ & $142.0, \mathrm{CH}$ \\
\hline 22 & $6.61, s$ & $6.61, s$ & 109.6, CH & $6.64, s$ & $6.34, s$ & $110.2, \mathrm{CH}$ \\
\hline 23 & $7.52, d(1.5)$ & $7.54, \mathrm{t}(1.5)$ & 144.9, $\mathrm{CH}$ & $7.62, \mathrm{~s}$ & $7.41, \mathrm{~s}$ & $143.0, \mathrm{CH}$ \\
\hline 28 & $0.88, \mathrm{~s}$ & $0.92, \mathrm{~s}$ & $15.5, \mathrm{CH}_{3}$ & $0.74, \mathrm{~s}$ & $0.76, \mathrm{~s}$ & 15.3, $\mathrm{CH}_{3}$ \\
\hline $29 a$ & $2.11, d(10.2)$ & $2.10, d(10.5)$ & $40.3, \mathrm{CH}_{2}$ & 2.16, d (11.0) & $1.98, \mathrm{~d}(11.3)$ & 42.6, $\mathrm{CH}_{2}$ \\
\hline $29 b$ & $1.69, d(10.2)$ & $1.83, \mathrm{~d}(10.5)$ & & $1.45, \mathrm{~d}(11.0)$ & 1.46, d (11.3) & \\
\hline 30 & $5.09, \mathrm{~s}$ & $5.14, \mathrm{~s}$ & 77.9, $\mathrm{CH}$ & $4.98, \mathrm{~d},(4.0)$ & 4.65, d (3.7) & $74.7, \mathrm{CH}$ \\
\hline 31 & & & $119.3, \mathrm{qC}$ & & & $119.8, \mathrm{qC}$ \\
\hline 32 & $1.68, \mathrm{~s}$ & $1.70, \mathrm{~s}$ & $16.4, \mathrm{CH}_{3}$ & $1.68, \mathrm{~s}$ & $1.68, \mathrm{~s}$ & 16.6, $\mathrm{CH}_{3}$ \\
\hline \multicolumn{7}{|l|}{ 2-OAC } \\
\hline \multirow[t]{2}{*}{ 3-OAC } & $2.00, \mathrm{~s}$ & $2.04, \mathrm{~s}$ & 21.7, $\mathrm{CH}_{3}$ & $1.97, \mathrm{~s}$ & $2.05, \mathrm{~s}$ & $21.8, \mathrm{CH}_{3}$ \\
\hline & & & 169.6, qC & & & $170.7, \mathrm{qC}$ \\
\hline \multirow[t]{2}{*}{ 6-OAC } & $2.24, \mathrm{~s}$ & $2.22, \mathrm{~s}$ & 21.0, $\mathrm{CH}_{3}$ & & & \\
\hline & & & 169.5, qC & & & \\
\hline \multirow[t]{2}{*}{$12-\mathrm{OAC}$} & & & & $1.59, \mathrm{~s}$ & $1.60, \mathrm{~s}$ & 19.9, $\mathrm{CH}_{3}$ \\
\hline & & & & & & $170.5, \mathrm{qC}$ \\
\hline \multicolumn{7}{|l|}{ 30-OAC } \\
\hline 7-OMe & $3.83, \mathrm{~s}$ & $3.76, \mathrm{~s}$ & $53.5, \mathrm{CH}_{3}$ & $3.74, s$ & $3.71, \mathrm{~s}$ & $52.1, \mathrm{CH}_{3}$ \\
\hline $1-\mathrm{OH}$ & & $3.50, \mathrm{~s}$ & & & & \\
\hline $2-\mathrm{OH}$ & & $3.54, \mathrm{~s}$ & & & & \\
\hline
\end{tabular}

[a] Measured in acetone- $d_{6}$, ${ }^{[b]}$ measured in $\mathrm{CDCl}_{3}$, and ${ }^{[c]}$ overlapped signals without designating multiplicity

contained a high content of 8,9,30-orthoesters, xyloccensins Q-S (7-9). A systematic literature check revealed that the 8,9,30-orthoesters were mainly distributed in the stem bark $[2,4,5]$, whereas the 1,8,9-orthoesters were found in the fruit, including the fruit rind and seeds $[3,6]$. In general, the stems and leaves of $X$. granatum are probably the main source of 8,9,30-orthoesters. Our research result was consistent with the conclusion that a high concentration of phragmalin orthoesters in the stem bark of Xylocarpus plants may serve as an important chemical defense against ecological invasion [3].

All isolated phragmalin orthoesters were subjected to the bioassay of inhibitory activity against protein tyrosine phosphatase $1 \mathrm{~B}$ (PTP1B), a potential drug target for the treatment of type II diabetes and obesity [26]. Of them, only xyloccensin S (9) showed in- hibitory activity with an $\mathrm{IC}_{50}$ value of $8.72 \mu \mathrm{g} / \mathrm{mL}$. Although limonoids were reported to possess various bioactivities [27], to the best of our knowledge, this is the first report of PTP1B inhibitory activities in limonoids.

\section{Materials and Methods \\ $\nabla$}

Plant material

The twigs and leaves of $X$. granatum $(2.0 \mathrm{~kg})$ were collected in December 2009 from Dongzhai Harbor, Hainan Province, China, and identified by Professor Guo-Rong Xin of the Institute of Biological Science, Sun Yat-Sen University. A voucher specimen (NO. 09- 
Table 2 NMR data for compounds 3 and 4.

\begin{tabular}{|c|c|c|c|c|c|c|}
\hline \multirow[b]{2}{*}{ Position } & \multicolumn{3}{|l|}{3} & \multicolumn{3}{|l|}{4} \\
\hline & $\delta_{\mathrm{H}}(V \text { in } \mathrm{Hz})^{[\mathrm{a}]}$ & $\delta_{\mathrm{H}}(V \text { in } \mathrm{Hz})^{[\mathrm{b}]}$ & $\delta_{c^{[b]}}$ & $\delta_{\mathrm{H}}(/ \text { in } \mathrm{Hz})^{[\mathrm{a}]}$ & $\delta_{\mathrm{H}}(V \text { in } \mathrm{Hz})^{[\mathrm{b}]}$ & $\delta_{C}^{[b]}$ \\
\hline 1 & & & $85.5, \mathrm{qC}$ & & & $85.4, \mathrm{qC}$ \\
\hline 2 & $4.08, \mathrm{dd}(12.0,4.0)$ & $4.11, \mathrm{dd}(12.0,4.1)$ & $34.5, \mathrm{CH}$ & $4.10, \mathrm{dd}(12.0,4.4)$ & $4.14, \mathrm{dd}(4.1,12.0)$ & $37.3, \mathrm{CH}$ \\
\hline 3 & $5.30, d(12.0)$ & $5.32, \mathrm{~d}(12.0)$ & $77.0, \mathrm{CH}$ & $5.26, d(12.0)$ & $5.27, \mathrm{~d}(12.0)$ & $77.4, \mathrm{CH}$ \\
\hline 4 & & & $46.0, \mathrm{qC}$ & & & 45.7, qC \\
\hline 5 & 2.37, d (12.0) & $2.23, \mathrm{~m}^{[\mathrm{c}]}$ & $39.1, \mathrm{CH}$ & 2.54 , brs & $2.51, \mathrm{~s}$ & $43.7, \mathrm{CH}$ \\
\hline $6 a$ & $3.18, d(17.0)$ & $3.16, \mathrm{~d}(16.5)$ & $32.9, \mathrm{CH}_{2}$ & $6.26, s$ & $6.36, s$ & $71.2, \mathrm{CH}$ \\
\hline $6 b$ & $2.47, \mathrm{dd}(17.0,12.0)$ & $2.23, \mathrm{~d}(16.5)$ & & & & \\
\hline 7 & & & 174.4, qC & & & 171.7, qC \\
\hline 8 & & & $81.1, \mathrm{qC}$ & & & $84.2, \mathrm{qC}$ \\
\hline 9 & & & $84.1, \mathrm{qC}$ & & & $81.0, \mathrm{qC}$ \\
\hline 10 & & & 49.3, qC & & & $50.2, \mathrm{qC}$ \\
\hline $11 a$ & $2.26, \mathrm{~m}$ & $2.23, \mathrm{~m}^{[\mathrm{c}]}$ & $32.7, \mathrm{CH}_{2}$ & 2.31, dd $(14.0,4.4)$ & $2.34, \mathrm{dd}(13.6,4.3)$ & $32.5, \mathrm{CH}_{2}$ \\
\hline $11 b$ & $2.04^{[c]}$ & $1.98, \mathrm{~m}$ & & $2.04^{[c]}$ & $2.00, \mathrm{~m}$ & \\
\hline 12 & $4.84, \mathrm{dd}(13.9,4.0)$ & $4.82, \mathrm{dd}(13.5,4.1)$ & $68.9, \mathrm{CH}$ & $5.04, \mathrm{dd}(13.5,4.5)$ & $4.98, \mathrm{dd}(13.6,4.2)$ & $68.7, \mathrm{CH}$ \\
\hline 13 & & & 42.9, qC & & & $42.9, \mathrm{qC}$ \\
\hline 14 & & & 154.5, qC & & & $154.4, \mathrm{qC}$ \\
\hline 15 & $6.67, s$ & $6.33, s$ & $122.9, \mathrm{CH}$ & $6.66, s$ & $6.30, s$ & $123.0, \mathrm{CH}$ \\
\hline 16 & & & 163.6, qC & & & 163.6, qC \\
\hline 17 & $5.95, \mathrm{~s}$ & $5.95, \mathrm{~s}$ & $78.8, \mathrm{CH}$ & $5.89, \mathrm{~s}$ & $5.94, s$ & $78.9, \mathrm{CH}$ \\
\hline 18 & $1.58, \mathrm{~s}$ & $1.62, \mathrm{~s}$ & $14.5, \mathrm{CH}_{3}$ & $1.58, \mathrm{~s}$ & $1.60, \mathrm{~s}$ & 14.4, $\mathrm{CH}_{3}$ \\
\hline 19 & $1.30, \mathrm{~s}$ & $1.26, \mathrm{~s}$ & $15.3, \mathrm{CH}_{3}$ & $1.29, \mathrm{~s}$ & $1.27, \mathrm{~s}$ & $16.2, \mathrm{CH}_{3}$ \\
\hline 20 & & & 121.2, qC & & & $121.1, \mathrm{qC}$ \\
\hline 21 & $7.49, \mathrm{~s}$ & $7.42, \mathrm{~s}$ & $142.0, \mathrm{CH}$ & 7.54, brs & $7.45, \mathrm{~s}$ & $142.0, \mathrm{CH}$ \\
\hline 22 & $6.63, d(1.7)$ & $6.55, d(1.3)$ & $110.2, \mathrm{CH}$ & 6.65 , brs & $6.56, d(1.5)$ & $110.2, \mathrm{CH}$ \\
\hline 23 & 7.61, brs & $7.40, d(1.6)$ & 143.0, CH & $7.62, \mathrm{t}(1.7)$ & $7.40, d(1.5)$ & $143.0, \mathrm{CH}$ \\
\hline 28 & $0.76, \mathrm{~s}$ & $0.77, \mathrm{~s}$ & $14.4, \mathrm{CH}_{3}$ & $0.96, \mathrm{~s}$ & $0.95, \mathrm{~s}$ & $15.5, \mathrm{CH}_{3}$ \\
\hline $29 a$ & $2.26, \mathrm{~m}$ & $2.46, d(11.6)$ & $39.0, \mathrm{CH}_{2}$ & $2.41, \mathrm{dd}(10.0,1.3)$ & 2.49, d (10.5) & $40.2, \mathrm{CH}_{2}$ \\
\hline $29 b$ & $1.55, \mathrm{~m}$ & $1.82, \mathrm{~d}(11.6)$ & & $1.40, d(10.0)$ & $2.11, \mathrm{~d}(10.5)$ & \\
\hline 30 & $4.82, d(4.0)$ & $4.49, \mathrm{~d}(4.0)$ & $73.4, \mathrm{CH}$ & $4.83, \mathrm{~d}(4.4)$ & $4.48, \mathrm{~d}(4.1)$ & $73.2, \mathrm{CH}$ \\
\hline 31 & & & 119.9, qC & & & 119.7, qC \\
\hline 32 & $1.59, \mathrm{~s}$ & $1.60, \mathrm{~s}$ & $16.7, \mathrm{CH}_{3}$ & $1.59, \mathrm{~s}$ & $1.62, \mathrm{~s}$ & 16.7, $\mathrm{CH}_{3}$ \\
\hline \multirow[t]{2}{*}{$1-O A C$} & $1.94, \mathrm{~s}$ & $1.99, \mathrm{~s}$ & $22.2, \mathrm{CH}_{3}$ & $1.94, \mathrm{~s}$ & $2.00, \mathrm{~s}$ & $22.2, \mathrm{CH}_{3}$ \\
\hline & & & $170.2, \mathrm{qC}$ & & & $170.2, q C$ \\
\hline \multirow[t]{2}{*}{ 3-OAC } & $1.97, \mathrm{~s}$ & $2.05, \mathrm{~s}$ & $21.8, \mathrm{CH}_{3}$ & $1.95, \mathrm{~s}$ & $2.03, \mathrm{~s}$ & $21.8, \mathrm{CH}_{3}$ \\
\hline & & & 170.6, qC & & & $170.4, q C$ \\
\hline \multirow[t]{2}{*}{ 6-OAC } & & & & $2.21, \mathrm{~s}$ & $2.20, \mathrm{~s}$ & $21.0, \mathrm{CH}_{3}$ \\
\hline & & & & & & 169.2, qC \\
\hline \multirow[t]{2}{*}{$12-\mathrm{OAC}$} & $1.51, \mathrm{~s}$ & $1.52, \mathrm{~s}$ & $19.9, \mathrm{CH}_{3}$ & $1.51, \mathrm{~s}$ & $1.55, \mathrm{~s}$ & $19.9, \mathrm{CH}_{3}$ \\
\hline & & & 170.6, qC & & & $170.5, \mathrm{qC}$ \\
\hline \multicolumn{7}{|l|}{$30-\mathrm{OAC}$} \\
\hline 7-OMe & $3.75, s$ & $3.72, \mathrm{~s}$ & $52.2, \mathrm{CH}_{3}$ & $3.81, \mathrm{~s}$ & $3.76, \mathrm{~s}$ & 53.3, $\mathrm{CH}_{3}$ \\
\hline
\end{tabular}

${ }^{[a]}$ Measured in acetone- $d_{6}$, ${ }^{[b]}$ measured in $\mathrm{CDCl}_{3}$, and ${ }^{[c]}$ overlapped signals without designating multiplicity

P-69) is available for inspection at the Herbarium of the Institute of Materia Medica, Chinese Academy of Sciences.

\section{Extraction and isolation}

The air-dried, powdered twigs and leaves of $X$. granatum $(2.0 \mathrm{~kg})$ were percolated with $\mathrm{MeOH}(10 \mathrm{~L} \times 3)$ at room temperature. The extract was evaporated to dryness under reduced pressure to give $154.0 \mathrm{~g}$ of residue. The residue was partitioned with EtOAc to afford $29.7 \mathrm{~g}$ of EtOAc extract. The EtOAc extract was separated by Sephadex $\mathrm{LH}-20\left(4 \times 100 \mathrm{~cm}, \mathrm{CHCl}_{3} / \mathrm{MeOH} 1: 1\right)$ and $\mathrm{MCI}$ gel column $\left(4 \times 40 \mathrm{~cm}, \mathrm{MeOH} / \mathrm{H}_{2} \mathrm{O} 30: 70,50: 50,80: 20,100: 0\right.$, each $2 \mathrm{~L}$ ) to obtain five fractions (Fr. 1-5). Fr. 3 (7.9 g) was subjected to silica gel vacuum liquid chromatography $(4 \times 100 \mathrm{~cm}, 800 \mathrm{~g})$, eluting with $\mathrm{CHCl}_{3} / \mathrm{MeOH}(100: 1,50: 1,20: 1,8: 2$, each $3 \mathrm{~L})$, to obtain 15 fractions. Fraction 4 (150.3 mg) was chromatographed on silica gel $(3.5 \times 30 \mathrm{~cm}, 12 \mathrm{~g})$ with petroleum ether/acetone $(95: 5$,
$8: 2,7: 3$, each $250 \mathrm{~mL}$ ) to yield 5 (>95\%, $4.6 \mathrm{mg}), 6$ (>95\%, $10.0 \mathrm{mg}$ ), and three subfractions, $4 \mathrm{a}-\mathrm{c}$. Fraction $4 \mathrm{a}$ was separated by Agilent semipreparative HPLC, eluting with $\mathrm{MeOH} / \mathrm{H}_{2} \mathrm{O}$ ( $73: 27$ ), to afford 3 (>98\%, $2.8 \mathrm{mg}, t_{\mathrm{R}} 31.5 \mathrm{~min}$ ), while compound $2\left(>98 \%, 2.4 \mathrm{mg}, t_{\mathrm{R}} 38.5 \mathrm{~min}\right)$ was prepared in the same manner using $\mathrm{MeOH} / \mathrm{H}_{2} \mathrm{O}(70: 30)$ from $4 \mathrm{~b}$. Fraction $4 \mathrm{c}$ was purified by reversed-phase HPLC, eluted with $\mathrm{MeOH} / \mathrm{H}_{2} \mathrm{O}(67: 33)$, to yield 4 (>98\%, $\left.1.3 \mathrm{mg}, t_{\mathrm{R}} 42.9 \mathrm{~min}\right)$. Fraction $5(2.17 \mathrm{~g}$ ) was subjected to column chromatography on silica gel $(6 \times 30 \mathrm{~cm}, 160 \mathrm{~g})$ eluted with a gradient of petroleum ether/acetone $(9: 1,8: 2,7: 3,1: 1$, each $600 \mathrm{~mL}$ ) to give four major fractions, $5 \mathrm{a}-5 \mathrm{~d}$. Fraction $5 \mathrm{c}$ was chromatographed over Sephadex LH-20 (3×120 cm), eluting with $\mathrm{CHCl}_{3} / \mathrm{MeOH}(1: 1)$, and subsequently purified by HPLC $\left(\mathrm{CH}_{3} \mathrm{CN} / \mathrm{H}_{2} \mathrm{O}, 67: 33\right)$ to give $\mathbf{1 0}\left(>98 \%, 4.0 \mathrm{mg}, t_{\mathrm{R}} 31.5 \mathrm{~min}\right)$. Fraction $5 \mathrm{~d}(0.51 \mathrm{~g})$ was subjected to column chromatography on silica gel $(3 \times 30 \mathrm{~cm}, 40 \mathrm{~g})$, eluted with petroleum ether/acetone 


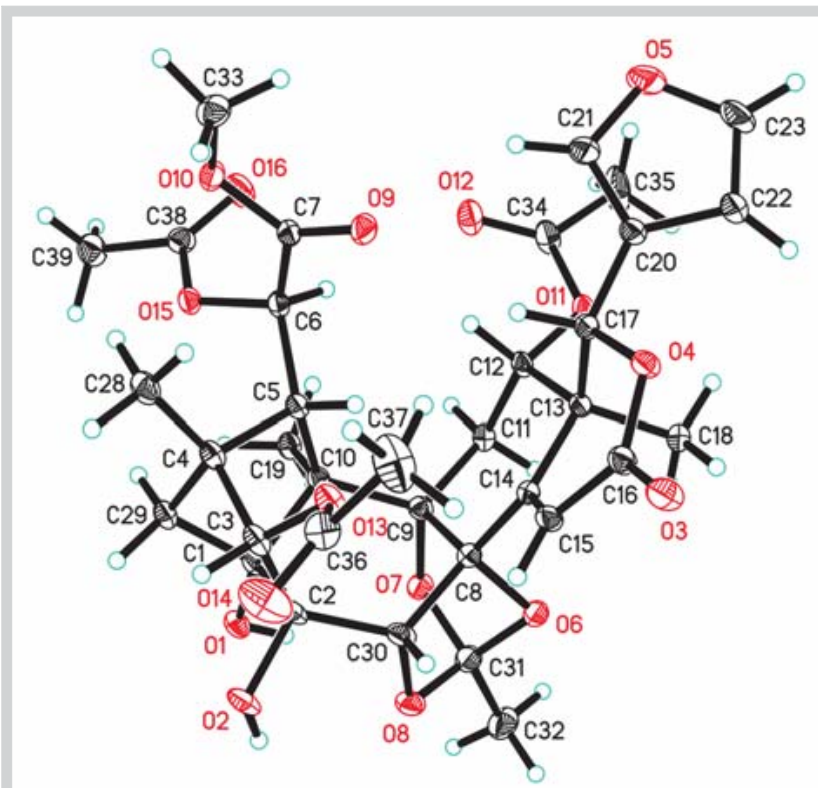

Fig. 2 X-ray crystal structure of 7. (Color figure available online only.)

$(7: 3,6: 4)$, to afford the major fraction $5 d 1$, which was further purified by HPLC $\left(\mathrm{MeOH} / \mathrm{H}_{2} \mathrm{O}, 70: 30\right)$ to yield 7 (>98\%, $10.0 \mathrm{mg}$, $t_{\mathrm{R}} 12.8 \mathrm{~min}$ ), 8 (> 98\%, $\left.4.4 \mathrm{mg}, t_{\mathrm{R}} 11.4 \mathrm{~min}\right), 9$ (>98\%, $6.5 \mathrm{mg}, t_{\mathrm{R}}$ $14.2 \mathrm{~min})$, and 1 (>98\%, $\left.1.5 \mathrm{mg}, t_{\mathrm{R}} 8.6 \mathrm{~min}\right)$.

(1): White amorphous powder; $[\alpha]_{D}^{20}+48.0$ (c 0.13, MeOH); IR $(\mathrm{KBr}) v_{\max } 3389,2954,2929,1731,1643,1421,1370,1237$, $1165,1091,1026 \mathrm{~cm}^{-1} ;{ }^{1} \mathrm{H}$ and ${ }^{13} \mathrm{C}$ NMR data, see - Table 1 ; HRESIMS $m / z$ 697.2105 [M + Na] $]^{+}$(calcd. for $\mathrm{C}_{33} \mathrm{H}_{38} \mathrm{O}_{15} \mathrm{Na}$, 697.2108). (2): White amorphous powder; $[\alpha]_{\mathrm{D}}^{20}+53.3\left(\right.$ c $\left.0.05, \mathrm{CH}_{3} \mathrm{CN}\right)$; ECD $\left(\mathrm{MeCN}, \lambda_{\max }[\mathrm{nm}](\Delta \varepsilon), c=7.91 \times 10^{-4}\right): 266$ (3.16), 214 (15.42). IR $(\mathrm{KBr}) v_{\max } 3410,2920,1735,1605,1422,1385,1239,1037 \mathrm{~cm}^{-1}$; ${ }^{1} \mathrm{H}$ and ${ }^{13} \mathrm{C}$ NMR data, see $\odot$ Table 1 ; HRESIMS m/z 655.2190 [M + $\mathrm{Na}]^{+}$(calcd. for $\mathrm{C}_{33} \mathrm{H}_{38} \mathrm{O}_{13} \mathrm{Na}, 655.2210$ ).

(3): Colorless gum; $[\alpha]_{\mathrm{D}}^{20}+94.7\left(c 0.025, \mathrm{CH}_{3} \mathrm{CN}\right)$; $\mathrm{ECD}(\mathrm{MeCN}$, $\left.\lambda_{\max }[\mathrm{nm}](\Delta \varepsilon), \quad c=1.46 \times 10^{-4}\right): 286$ (3.34), 260 (1.71), 211 (5.38). IR (KBr) $v_{\max } 2985,1740,1610,1422,1400,1240$, $1035 \mathrm{~cm}^{-1}$; ${ }^{1} \mathrm{H}$ and ${ }^{13} \mathrm{C}$ NMR data, see $\bigcirc$ Table 2; HRESIMS $\mathrm{m} / \mathrm{z}$ 707.2319 [M + Na $]^{+}$(calcd. for $\mathrm{C}_{35} \mathrm{H}_{40} \mathrm{O}_{14} \mathrm{Na}$, 707.2316).

(4): Colorless gum; $[\alpha]_{\mathrm{D}}^{20}+40\left(c \mathrm{0.03}, \mathrm{CH}_{3} \mathrm{CN}\right)$; IR $(\mathrm{KBr}) v_{\max } 2900$, $1735,1600,1412,1375,1240,1027 \mathrm{~cm}^{-1} ;{ }^{1} \mathrm{H}$ and ${ }^{13} \mathrm{C}$ NMR data, see Table 2; HRESIMS $m / z 765.2362[\mathrm{M}+\mathrm{Na}]^{+}$(calcd. for $\mathrm{C}_{37} \mathrm{H}_{42} \mathrm{O}_{16} \mathrm{Na}, 765.2371$ ).

\section{Supporting information}

Original spectra for compounds $\mathbf{1 - 4}$, the CD spectra, details regarding the experimental protocols, and crystal data for xyloccensin Q (7) are available as Supporting Information.

\section{Acknowledgements}

$\nabla$

This research work was financially supported by the National Marine '863' Project (Nos. 2011AA09070102 and 2013AA092902), the Natural Science Foundation of China (No. 81273430), the SKLDR/SIMM Projects (No. SIMM 1203ZZ-03), and Syngenta-SIMM-PhD Studentship Project, and partially funded by the SKLNM/CPU project (No. SKLNMKF 201412). T.K. and A.M. thank the Hungarian National Research Foundation for financial suppport (OTKA K105871, K81701) and the National Information Infrastructure Development Institute (NIIFI 10038).

\section{Conflict of Interest}

\section{7}

The authors declare no conflict of interest.

\section{References}

1 Liao SG, Chen HD, Yue JM. Plant orthoesters. Chem Rev 2009; 109: 1092-1140

2 Wu J, Xiao Q Huang JS, Xiao ZH, Qi SH, Li QX, Zhang S. Xyloccensins O and $\mathrm{P}$, unique 8, 9, 30-phragmalin ortho esters from Xylocarpus granatum. Org Lett 2004; 6: 1841-1844

3 Cui JX, Wu J, Deng ZW, Proksch P, Lin WH. Xylocarpins A-I, limonoids from the Chinese mangrove plant Xylocarpus granatum. J Nat Prod 2007; 70: 772-778

4 Wu J, Xiao Q Zhang S, Li X, Xiao ZH, Ding HX, Li QX. Xyloccensins Q-V, six new 8, 9, 30-phragmalin ortho ester antifeedants from the Chinese mangrove Xylocarpus granatum. Tetrahedron 2005; 61: 8382-8389

5 Cui JX, Deng ZW, Li J, Fu HZ, Proksch P, Lin WH. Phragmalin-type limonoids from the mangrove plant Xylocarpus granatum. Phytochemistry 2005; 66: 2334-2339

6 Pan JY, Chen SL, Li MY, Li J, Yang MH, Wu J. Limonoids from the Seeds of a Hainan Mangrove, Xylocarpus granatum. J Nat Prod 2010; 73: 16721679

7 Shen LR, Guo D, Yu YM, Yin BW, Zhao L, Shi QW, Wang YL, Huo CH. Chemical constituents of plants from the genus Xylocarpus. Chem Biodivers 2009; 6: 1293-1308

8 Li MY, Wu J, Zhang S, Xiao Q Li QX. The absolute stereochemistry of protoxylogranatin A - a new protolimonoid from the seeds of Chinese mangrove Xylocarpus granatum. J Asian Nat Prod Res 2008; 10: $503-$ 508

9 Cui JX, Deng ZW, Xu MJ, Proksch P, Li QS, Lin WH. Protolimonoids and limonoids from the Chinese mangrove plant Xylocarpus granatum. Helv Chim Acta 2009; 92: 139-150

10 Li MY, Yang XB, Pan JY, Feng G, Xiao Q, Sinkkonen J, Satyanandamurty T, $W u \mathrm{~J}$. Granatumins A-G, limonoids from the seeds of a Krishna mangrove, Xylocarpus granatum. J Nat Prod 2009; 72: 2110-2114

11 Pudhom K, Sommit D, Nuclear P, Ngamrojanavanich N, Petsom A. Protoxylocarpins F-H, protolimonoids from seed kernels of Xylocarpus granatum. J Nat Prod 2009; 72: 2188-2191

12 Shen LR, Dong $M$, Guo D, Yin BW, Zhang ML, Sha QW, Huo CH, Kiyota $H$, Suzuki $N$, Cong B. Xylomexicanins A and B, new $\Delta^{14,15}$-mexicanolides from seeds of the Chinese mangrove Xylocarpus granatum. Z Naturforsch C 2009; 64: 37-42

13 Huo CH, Guo D, Shen LR, Yin BW, Sauriol F, Li LG, Zhang ML, Shi QW, Kiyota $\mathrm{H}$. Xylocarpanoids A and B, unique C-28 skeleton limonoids from $X y$ locarpus granatum. Tetrahedron Lett 2010; 51: 754-757

14 Li J, Li MY, Bruhn T, Götz DCG, Xiao Q Satyanandamurty T, Wu J, Bringmann $G$. Andhraxylocarpins A-E: structurally intriguing limonoids from the true mangroves Xylocarpus granatum and Xylocarpus moluccensis. Chem Eur J 2012; 18: 14342-14351

15 Wu YB, Qing X, Huo CH, Yan HM, Shi QW, Sauriol F, Gu YC, Kiyota H. Xylomexicanins $\mathrm{E}-\mathrm{H}$, new limonoids from Xylocarpus granatum. Tetrahedron 2014; 70: 4557-4562

16 Wu Y, Bai Y, Guo X, Qi J, Dong M, Sauriol F, Shi Q Gu Y, Huo C. A new limonoid from Xylocarpus granatum. Chem Nat Compd 2014; 50: 314-316

17 Li MY, Xiao Q Satyanandamurty T, Wu J. Limonoids with an oxygen bridge between $\mathrm{C}(1)$ and $\mathrm{C}(29)$ from the seeds of a Krishna mangrove, Xylocarpus granatum. Chem Biodivers 2014; 11: 262-275

18 Chen W, Shen L, Li M, Xiao Q Satyanandamurty T, Wu J. Absolute configurations of new limonoids from a Krishna mangrove, Xylocarpus granatum. Fitoterapia 2014; 94: 108-113

19 Wu YB, Ni ZY, Huo CH, Su J, Dong M, Sauriol F, Shi QW, Gu YC, Kiyota H. Xylomexicanins $C$ and D, new mexicanolide-type limonoids from Xylocarpus granatum. Biosci Biotechnol Biochem 2013; 77: 736-740

20 Toume K, Kamiya K, Arai MA, Mori N, Sadhu SK, Ahmed F, Ishibashi M. Xylogranin B: a potent Wnt signal inhibitory limonoid from Xylocarpus granatum. Org Lett 2013; 15: 6106-6109 
21 Chen H, Zhang J, Li MY, Satyanandamurty T, Wu J. New limonoids from the seeds of a Krishna mangrove, Xylocarpus granatum. Chem Biodivers 2013; 10: 612-620

22 Pescitelli G, Kurtán T, Flörke U, Krohn K. Absolute structural elucidation of natural products-a focus on quantum-mechanical calculations of solid-state CD spectra. Chirality 2009; 21: E181-E201

23 Krohn K, Farooq U, Flörke U, Schulz B, Draeger S, Pescitelli G, Salvadori P, Antus S, Kurtán T. Secondary metabolites isolated from an endophytic Phoma sp. - absolute configuration of tetrahydropyrenophorol using the solid-state TDDFT CD methodology. Eur J Org Chem 2007; 2007: 3206-3211

24 Zhang W, Krohn K, Ding J, Miao ZH, Zhou XH, Chen SH, Pescitelli G, Salvadori P, Kurtan T, Guo YW. Structural and stereochemical studies of $\alpha$ - methylene- $\gamma$-lactone-bearing cembrane diterpenoids from a south china sea soft coral Lobophytum crassum. J Nat Prod 2008; 71: 961-966 25 Oin S, Krohn K, Flörke U, Schulz B, Draeger S, Pescitelli G, Salvadori P, Antus $S$, Kurtán T. Two new fusidilactones from the fungal endophyte $\mathrm{Fu}$ sidium sp. Eur J Org Chem 2009; 2009: 3279-3284

26 Elchebly M, Payette P, Michaliszyn E, Cromlish W, Collins S, Loy AL, Normandin D, Cheng A, Himms-Hagen J, Chan CC, Ramachandran C, Gresser MJ, Tremblay ML, Kennedy BP. Increased insulin sensitivity and obesity resistance in mice lacking the protein tyrosine phosphatase-1B gene. Science 1999; 283: 1544-1548

27 Tan QG, Luo XD. Meliaceous limonoids: chemistry and biological activities. Chem Rev 2011; 111: 7437-7522 